\title{
Physicochemical Properties and Freshness of Spent Hen's Meat under Frozen or Refrigeration Conditions after Thawing
}

\author{
Hyo-Jung Gu, Ja-Gyeong Gu${ }^{1}$, Jung-Min Park¹, Su-Jin Yoon ${ }^{1}$, Jeong-Soo Lee ${ }^{1}$, Ji-Hui An¹, \\ Jang-Mi Kim ${ }^{1}$, Byoung-Ki $\mathrm{An}^{2}$, Chang-Won Kang ${ }^{2}$, and Jin-Man $\mathrm{Kim}^{1 *}$ \\ Korea Livestock Products HACCP Accreditation Service, Anyang 430-821, Korea \\ ${ }^{I}$ Department of Food Science and Biotechnology of Animal Resources, Konkuk University, Seoul 143-701, Korea \\ ${ }^{2}$ Animal Resources Research Center, College of Animal Bioscience and Technology, Konkuk University, Seoul 143-701, Korea
}

\begin{abstract}
This study was conducted in order to investigate the effect of storage temperature abuse on the freshness of refrigerated and frozen spent hen's meat. After a room temperature storage condition, two different storage temperature were followed: refrigeration and frozen storage. All parts of the spent hen's meats were thawed at $4 \mathrm{~d}$ intervals up to 3 times $(2,6$, and 10 d) for $24 \mathrm{~h}$. The level of bacteria on the different parts of the refrigerated and frozen meats was higher than 6 Log CFU/g under the following storage conditions: refrigerated - breast, $12 \mathrm{~h}$; leg, $6 \mathrm{~h}$; wing, $12 \mathrm{~h}$ at the $1^{\text {st }}$ analysis, frozen - breast, 12 $\mathrm{h}$ at the $2^{\text {nd }}$ analysis; leg, $24 \mathrm{~h}$ at the $1^{\text {st }}$ analysis; wing, $12 \mathrm{~h}$ at the $1^{\text {st }}$ analysis. The $\mathrm{pH}$ value for the leg meat was higher than breast and wing meats. In the color measurements, under the room temperature storage condition, lightness and redness values decreased but the yellowness increased in refrigerated meats $(p<0.05)$. The $\mathrm{K}$-value regarding refrigerated leg meats exceeded $60 \%$, which is the threshold value to evaluate the degree of freshness, during the $1^{\text {st }}$ analysis $(p<0.05)$. The VBN value of refrigerated leg meat was the highest and reached up to $96.93 \mathrm{mg} \%$. Thus, studies regarding the possible decline in quality according to the change of storage temperature could be used in order to establish a basic database for the quality control of spent hen meat being traded with other countries.
\end{abstract}

Key words: spent hen, shelf-life, freshness, temperature abuse, thawing

\section{Introduction}

In recent years, food safety has become highly important due to the globalization and free trade in the food industry (Likar and Jevšnik, 2006). Consumer demand for highly qualified and safer food has increased. However, incidence of Salmonella, which was the most common infection associated with food, were reported to occur 1.2 millions in the United States annually (CDCP, 2010). Especially, raw poultry products are perceived to be related with a significant amount of food poisoning due to the frequent cases of poultry contaminated with pathogens (Kessel et al., 2001; Zhao et al., 2001). Also, it was reported that these sorts of disease can be caused by temperature abuse during storage and distribution (Juneja et al., 2007). For this reason, the cold chain system is rec-

\footnotetext{
*Corresponding author: Jin-Man Kim, Department of Food Science and Biotechnology of Animal Resources, Konkuk University, Seoul 143-701, Korea. Tel: 82-2-450-3688, Fax: 82-2-455-1044, E-mail: jinmkim@konkuk.ac.kr
}

ommended as the most effective way to ensure freshness and safety of food products. Easily, perishable food products such as dairy products and fresh poultry meat, have a short durability and sell time so that distributors must ensure that appropriate storage temperatures are used.

Tenderness is the most important sensory characteristic of meat (Lawrie, 1991). However, the meat obtained from spent hens has poor quality attributes, such as toughness, which has decreased its remunerative price (Vaithiyanathan et al., 2008). On the other hands consumers in certain regions of East-South Asian countries, especially Vietnam, have a preference for spent hen meat. According to the Korean Agro-Fisheries Trade Corp. and Animal Plant \& Fisheries Quarantine \& Inspection Agency, spent hen exports have increased annually, most of which is sold to Vietnam (REPP, 2010). However, those countries has not equipped with efficient cold chain systems, so unfavorable changes related with freshness and quality attributes occur frequently in East-South Asia. Thus, there is a need to apply the cold chain system to ensure food safety during distribution, which would be very important 
not only to foreign consumers but also to Korean spent hen exporters.

Considering retail environment in certain East-South Asian Counties, study for possible decline in quality according to the change of storage temperature is needed. Therefore, the aim of this study was to examine the effect of storage temperature abuse on spent hen meats in regards to the shelf-life, using the $\mathrm{K}$-value and volatile basic nitrogen (VBN), which have been used as physicochemical indicators of poultry. The results obtained in this study could be used to establish a basic database for the quality control of spent hen meat that is traded with East-South countries.

\section{Materials and Methods}

\section{Samples preparation and condition of storage tem- perature}

Frozen and refrigerated cuts of spent hen's meat (breast, leg, and wing) were obtained from a commercial slaughter house (JUNG WOO FOOD CO., LTD, Korea). Breast and leg meats deboned manually in commercial poultry processing unit and subcutaneous fat and visible connective tissue were removed. A total of samples ( 2 treatment $\times 15$ times $\times 3$ replication) were prepared for triplicate a parts and each cuts of spent hen's meat (30 g) samples vacuum-packed using a vacuum packer (FJ-500XL, Fujee Tech, Korea) and stored at $4^{\circ} \mathrm{C}$ and $-18^{\circ} \mathrm{C}$. In this study, the method of storage was divided into two groups: (a) refrigerated condition $\left(4^{\circ} \mathrm{C}\right)$ followed by storage at room temperature $\left(20^{\circ} \mathrm{C}\right)$, and $(\mathrm{b})$ frozen condition $\left(-18^{\circ} \mathrm{C}\right)$ followed by storage at room temperature $\left(20^{\circ} \mathrm{C}\right)$, which is 1 cycle, repeated up to 3 times. While storage periods, at 4 $\mathrm{d}$ intervals $(2,6$, and $10 \mathrm{~d})$, all parts of the refrigerated and frozen meats were exposed at room temperature for $24 \mathrm{~h}$. On room temperature condition, random carcasses were analyzed for 5 times $(0,2,6,12$, and $24 \mathrm{~h})$ and then remaining samples were restored at refrigerated and frozen conditions, respectively for $2^{\text {nd }}$ and $3^{\text {rd }}$ analysis. In the case of wing meats, skin was removed for analysis with the exception of color analysis.

\section{Microbiological analysis}

Samples were removed from the vacuum packaging using a sterile scalpel at $0,2,6,12$, and $24 \mathrm{~h}$ under room temperature. Sample $(5 \mathrm{~g})$ was placed in $45 \mathrm{~mL}$ of $0.1 \%$ peptone water in a sterile stomacher bag and homogenized using a Stomacher (Stomacher 400 Circulator, UK) for 2 min. The samples were then serially diluted with peptone water for microbial counts. Plate count agar (PCA, Difco, USA) was used to obtain the total viable cell counts and experiments were performed in triplicate. The plates were incubated at $37^{\circ} \mathrm{C}$ for $48 \mathrm{~h}$. Total viable cell counts were calculated as the mean of three determinations and expressed as Log CFU (colony forming unit)/g.

\section{pH evaluation}

The $\mathrm{pH}$ value of the samples were measured in homogenate prepared with $5 \mathrm{~g}$ samples with $20 \mathrm{~mL}$ distilled water at 2,000 rpm for $2 \mathrm{~min}$ in a homogenizer (Model AM-7, Nissei, Japan). The $\mathrm{pH}$ values were measured using a digital $\mathrm{pH}$ meter (F-51, Horiba, Japan) calibrated at $\mathrm{pH}$ 4.0 and 7.0 .

\section{Color evaluation}

Color measurements were performed using a color meter (Chromameter, CR210, Minolta, Japan; illuminate $\mathrm{C}$, calibrated with white standard plate $\mathrm{L}^{*}=+97.83, \mathrm{a}^{*}=$ $-0.43, \mathrm{~b}^{*}=+1.98$ ). The measured region was $8 \mathrm{~mm}$ in diameter and the measured area and illumination area was $50 \mathrm{~nm}$ in diameter. Color values (CIE L ${ }^{*}, \mathrm{CIE} \mathrm{a}^{*}$, and CIE $b^{*}$ ) were measured on the surface of the samples and measurements were acquired in triplicate for each sample.

\section{K-value evaluation}

To calculate the K-value, $200 \mathrm{mg}$ of samples and 600 $\mu \mathrm{L}$ of perchloric acid were placed in an eppendorf tube in order to precipitate the protein. The solution was then neutralized with $40-50 \mu \mathrm{L}$ of $\mathrm{KOH}$. The K-value was calculated with a freshness checker system (Freshness checker system HF-1000, Huetech, Korea), which can divide ATP and ATP-related compounds into two spots : (a) ATP, ADP, AMP and IMP with negative charge because of phosphate groups, (b) $\mathrm{H}_{\mathrm{X}} \mathrm{R}$ and $\mathrm{H}_{\mathrm{X}}$ with charge neutrality. It was detected by electrophoresis and visualized under UV illumination at $250 \mathrm{~nm}$. The amounts of ATP and ATP-related compounds were estimated using the following formula, as described by Saito et al. (1959).

$$
\begin{aligned}
\text { K-value }(\%)= & \left({ }^{1} \mathrm{HxR}+{ }^{2)} \mathrm{Hx}\right) \times 100 /\left({ }^{3)} \mathrm{ATP}+{ }^{4)} \mathrm{ADP}\right. \\
& \left.+{ }^{5)} \mathrm{AMP}+{ }^{6} \mathrm{IMP}+\mathrm{HxR}+\mathrm{Hx}\right)
\end{aligned}
$$

${ }^{1)} \mathrm{HxR}$, hypoxanthine; ${ }^{2} \mathrm{Hx}$, inosine; ${ }^{3)} \mathrm{ATP}$, adenosine triphosphate; ${ }^{4)} \mathrm{ADP}$, adenosine diphosphate; ${ }^{5)} \mathrm{AMP}$, adenosine monophosphate; ${ }^{6} \mathrm{IMP}$, inosine monophosphate.

*The lower the K-value, the fresher the meat.

\section{Volatile Basic Nitrogen (VBN) evaluation}

Volatile basic nitrogen $\left(\mathrm{mg}^{\circ}\right)$ tests were conducted to 
assess the extent of protein deterioration by proteolysis during storage. VBN was measured using the modified micro-diffusion assay according to the method described by Pearson (1968).

$$
\begin{aligned}
& \text { VBN }(\mathrm{mg} \%) \\
& =(\mathrm{a}-\mathrm{b}) \times(\mathrm{f} \times 0.02 \times \mathrm{N} \times 14.007 \times 100 \times 100) / \mathrm{S}
\end{aligned}
$$

Where, $a=$ titer for sample, $b=$ titer for blank, $f=$ factor of reagent, $\mathrm{N}=$ normality, $\mathrm{S}=$ sample weight $(\mathrm{g})$

\section{Statistical analysis}

An analysis of variance were performed on all the variables measure using the General Linear Model (GLM) procedure in the SAS software (SAS, 2002). Duncan's multiple range test $(p<0.05)$ was used to determine difference between treatment mean applied. All data were expressed as mean \pm standard deviation.

\section{Results and Discussion}

\section{Microbiological analysis}

The microflora present on poultry is carried into the slaughter house and processing facility on the body and in the alimentary tract of the birds. Under proper conditions, the technological counts of bacteria range from 1 to 3 Log CFU/g (Sofos and Smith, 1998). The number of microflora on carcasses after washing and cooling were reported to be approximately $3.58 \mathrm{Log} \mathrm{CFU} / \mathrm{cm}^{2}$ (Gill et al., 2006).

In this study, the microflora of refrigerated spent hen meats increased from approximately 4.00 to $7.85 \mathrm{Log}$ $\mathrm{CFU} / \mathrm{g}$ and the bacterial counts on the frozen spent hen's meats ranged from 3.60 to $7.66 \mathrm{Log} \mathrm{CFU} / \mathrm{g}$ during the thawing periods (Table 1). Barnes (1976) indicated that the phase of initial spoilage occurs when the number of microflora in poultry meat is more than $6 \mathrm{Log} \mathrm{CFU} / \mathrm{g}$. In this study, the bacterial counts on the refrigerated and frozen cuts of spent hen's meat exceeded this value when stored under the following conditions: refrigerated - breast, $12 \mathrm{~h}$; leg, $6 \mathrm{~h}$; wing, $12 \mathrm{~h}$ at the $1^{\text {st }}$ analysis, frozen - breast, $12 \mathrm{~h}$ at the $2^{\text {nd }}$ analysis; leg, $24 \mathrm{~h}$ at the $1^{\text {st }}$ analysis; wing, $12 \mathrm{~h}$ at the $1^{\text {st }}$ analysis. There were substantial differences in the growth rate among cut of refrigerated and frozen spent meat. An unpleasant odor was detected when the total number of bacteria reached $7 \mathrm{Log}$ CFU/g bacteria for both refrigerated and frozen spent hen meat. Especially, during the $1^{\text {st }}$ analysis, all parts of the refrigerated meats were incrusted with slime. In previous study, Sofos et al. (2000) reported that the number of microflora was more than $7 \mathrm{Log}$ CFU/g if spoilage could be visibly detected.

Thomas and Mathews (2005) reported that temperature plays an important role in microbial growth and spoilage

\begin{tabular}{|c|c|c|c|c|c|c|c|}
\hline \multirow{3}{*}{\multicolumn{2}{|c|}{$\begin{array}{l}\text { Analysis procedures \& } \\
\text { Storage periods }(\mathrm{h})\end{array}$}} & \multicolumn{6}{|c|}{ Parts } \\
\hline & & \multicolumn{3}{|c|}{ Refrigeration $^{1)}$} & \multicolumn{3}{|c|}{ Frozen $^{2)}$} \\
\hline & & Breast & Leg & Wing & Breast & Leg & Wing \\
\hline \multirow{5}{*}{$\begin{array}{l}1^{\text {st }} \text { analysis } \\
\text { on room } \\
\text { temperature }\end{array}$} & $2 d+0$ & $4.72 \pm 0.02^{\mathrm{J} 33}$ & $4.66 \pm 0.12^{\mathrm{M}}$ & $4.00 \pm 0.13^{\mathrm{M}}$ & $3.77 \pm 0.10^{\mathrm{M}}$ & $4.01 \pm 0.08^{\mathrm{M}}$ & $3.60 \pm 0.11^{\mathrm{N}}$ \\
\hline & $2 d+2$ & $5.52 \pm 0.03^{\mathrm{J}}$ & $5.85 \pm 0.04^{\mathrm{L}}$ & $4.56 \pm 0.15^{\mathrm{L}}$ & $4.04 \pm 0.08^{\mathrm{L}}$ & $4.58 \pm 0.06^{\mathrm{L}}$ & $3.85 \pm 0.09^{\mathrm{L}}$ \\
\hline & $2 d+6$ & $5.82 \pm 0.01^{\mathrm{H}}$ & $6.14 \pm 0.26^{\mathrm{K}}$ & $5.57 \pm 0.02^{\mathrm{K}}$ & $4.88 \pm 0.04^{\mathrm{J}}$ & $5.11 \pm 0.1^{\mathrm{K}}$ & $3.78 \pm 0.04^{\mathrm{M}}$ \\
\hline & $2 d+12$ & $6.34 \pm 0.33^{\mathrm{F}}$ & $6.48 \pm 0.08^{\mathrm{J}}$ & $6.58 \pm 0.22^{\mathrm{J}}$ & $4.49 \pm 0.05^{\mathrm{K}}$ & $5.92 \pm 0.07^{\mathrm{J}}$ & $6.34 \pm 0.17^{\mathrm{J}}$ \\
\hline & $2 d+24$ & $7.23 \pm 0.44^{\mathrm{C}}$ & $7.29 \pm 0.39^{\mathrm{B}}$ & $7.17 \pm 0.41^{\mathrm{D}}$ & $5.79 \pm 0.04^{\mathrm{G}}$ & $6.70 \pm 0.32^{\mathrm{F}}$ & $6.69 \pm 0.66^{\mathrm{D}}$ \\
\hline \multirow{5}{*}{$\begin{array}{l}2^{\text {nd }} \text { analysis } \\
\text { on room } \\
\text { temperature }\end{array}$} & $6 \mathrm{~d}+0$ & $6.51 \pm 0.13^{\mathrm{E}}$ & $6.87 \pm 0.19^{\mathrm{H}}$ & $6.81 \pm 0.13^{\mathrm{J}}$ & $5.63 \pm .0 .36^{\mathrm{H}}$ & $6.56 \pm 0.07^{\mathrm{G}}$ & $6.59 \pm 0.24^{\mathrm{F}}$ \\
\hline & $6 \mathrm{~d}+2$ & $6.37 \pm 0.04^{\mathrm{F}}$ & $6.86 \pm 0.20^{\mathrm{H}}$ & $7.29 \pm 0.32^{\mathrm{C}}$ & $5.59 \pm 0.52^{\mathrm{I}}$ & $6.27 \pm 0.29^{\mathrm{I}}$ & $6.37 \pm 0.18^{\mathrm{I}}$ \\
\hline & $6 \mathrm{~d}+6$ & $6.14 \pm 0.08^{\mathrm{G}}$ & $6.47 \pm 0.15^{\mathrm{J}}$ & $7.15 \pm 0.15^{\mathrm{E}}$ & $5.78 \pm 0.24^{\mathrm{G}}$ & $6.44 \pm 0.24^{\mathrm{H}}$ & $6.46 \pm 0.11^{\mathrm{H}}$ \\
\hline & $6 d+12$ & $6.35 \pm 0.03^{\mathrm{F}}$ & $6.70 \pm 0.05^{\mathrm{I}}$ & $7.01 \pm 0.02^{\mathrm{F}}$ & $6.04 \pm 0.31^{\mathrm{F}}$ & $6.57 \pm 0.04^{\mathrm{G}}$ & $6.66 \pm 0.11^{\mathrm{E}}$ \\
\hline & $6 \mathrm{~d}+24$ & $6.63 \pm 0.07^{\mathrm{E}}$ & $7.12 \pm 0.02^{\mathrm{E}}$ & $7.08 \pm 0.07^{\mathrm{G}}$ & $6.42 \pm 0.04^{\mathrm{E}}$ & $6.71 \pm 0.04^{\mathrm{EF}}$ & $6.93 \pm 0.02^{\mathrm{A}}$ \\
\hline \multirow{5}{*}{$\begin{array}{l}3^{\text {rd }} \text { analysis } \\
\text { on room } \\
\text { temperature }\end{array}$} & $10 \mathrm{~d}+0$ & $6.54 \pm 0.05^{\mathrm{E}}$ & $7.08 \pm 0.04^{\mathrm{F}}$ & $7.10 \pm 0.05^{\mathrm{H}}$ & $6.53 \pm 0.08^{\mathrm{D}}$ & $6.75 \pm 0.11^{\mathrm{D}}$ & $6.87 \pm 0.07^{\mathrm{B}}$ \\
\hline & $10 \mathrm{~d}+2$ & $6.87 \pm 0.11^{\mathrm{D}}$ & $7.18 \pm 0.26^{\mathrm{D}}$ & $7.47 \pm 0.15^{\mathrm{B}}$ & $6.77 \pm 0.30^{\mathrm{C}}$ & $6.72 \pm 0.19^{\mathrm{E}}$ & $6.77 \pm 0.16^{\mathrm{C}}$ \\
\hline & $10 \mathrm{~d}+6$ & $7.85 \pm 0.13^{\mathrm{A}}$ & $7.36 \pm 0.42^{\mathrm{A}}$ & $7.64 \pm 0.29^{\mathrm{A}}$ & $7.30 \pm 0.47^{\mathrm{B}}$ & $7.66 \pm 0.28^{\mathrm{A}}$ & $6.28 \pm 0.13^{\mathrm{K}}$ \\
\hline & $10 \mathrm{~d}+12$ & $7.68 \pm 0.15^{\mathrm{B}}$ & $7.24 \pm 0.15^{\mathrm{C}}$ & $7.46 \pm 0.24^{\mathrm{B}}$ & $7.45 \pm 0.07^{\mathrm{A}}$ & $7.35 \pm 0.13^{\mathrm{B}}$ & $6.37 \pm 0.43^{\mathrm{I}}$ \\
\hline & $10 d+24$ & $7.32 \pm 0.22^{\mathrm{C}}$ & $7.06 \pm 0.11^{\mathrm{G}}$ & $7.08 \pm 0.28^{\mathrm{G}}$ & $7.30 \pm 0.32^{\mathrm{B}}$ & $6.96 \pm 0.17^{\mathrm{C}}$ & $6.56 \pm 0.35^{\mathrm{G}}$ \\
\hline
\end{tabular}

Table 1. Total viable cell counts of spent hen's meat at different storage temperatures under room temperature storage condition

Unit : Log CFU (colony forming unit)/g.

${ }^{1)}$ Samples (stored at refrigerated condition) to room temperature

${ }^{2}$ Samples (stored at frozen condition) to room temperature

${ }^{3)}$ Means \pm SD

${ }^{\text {A-N }}$ Means with the different superscript in the same column are significantly different $(p<0.05)$. 
of meat or meat products. Since microbial spoilage results in physicochemical changes, the initial microbial count is one of the most important parameters in determining the shelf-life of poultry meats (Cunningham, 1982).

\section{pH}

The changes in $\mathrm{pH}$ values of refrigerated and frozen spent hen meats were affected by storage temperature under room temperature storage condition (Table 2).

Differences in postmortem $\mathrm{pH}$ values were observed among the three parts (breast, leg and wing) of spent hens. Under room temperature storage condition, changes in $\mathrm{pH}$ values of three parts of refrigerated meats were as follows: breast; 5.87-6.72, leg; 6.56-7.36, and wing; 6.24$7.20(p<0.05)$. In the case of frozen meats, the changes in $\mathrm{pH}$ values were as follows: breast; 5.91-6.19, leg; 6.437.27, and wing; 6.41-6.84 ( $p<0.05)$. Based on these findings, the $\mathrm{pH}$ value of the leg was shown to be higher than breast and wing. These results were consistence with those of Lesiak et al. (1996) and Northcutt et al. (2001), who reported that the $\mathrm{pH}$ value of leg meats was approximately 0.2-0.3 higher than that of breast meats of poultry. Geesink et al. (1995) also reported that the rate of the temperature decrease and type of muscle were also important determinants of the decrease in $\mathrm{pH}$ post mortem.

In generally, the $\mathrm{pH}$ fall will result from (a) denaturation of sacroplasmic proteins and myofibrillar proteins, (b) increase of actomyosin shortening and (c) internal structural changes (Offer and Trinick, 1983; Offer and Knight, 1988).

\section{Color}

The lightness, redness, and yellowness of refrigerated and frozen spent hen's meats during storage were significantly affected by storage temperature abuse (Table 3 and 4).

In the case of refrigerated wing meats, the yellowness were not influenced by storage temperature by elapsing storage periods until $2^{\text {nd }}$ analysis $(p<0.05)$. After $2^{\text {nd }}$ analysis no significant difference were observed in the lightness. The yellowness of spent hen breast meats increased, while the redness values significantly decreased during refrigerated storage $(p<0.05)$. Akamittath et al. (1990) reported that redness decreased with an increase in storage time because of metmyoglobin. When refrigerated meats were compared with frozen meats, the yellowness of the refrigerated wing meat was much higher than that of frozen wing meat, but the lightness value of frozen leg meat was higher than that of refrigerated leg meat.

Green color in meats results from sulphmyoglobin, when myoglobin reacts with (a) hydrogen sulphide $\left(\mathrm{H}_{2} \mathrm{~S}\right)$ and (b) hydrogen peroxide $\left(\mathrm{H}_{2} \mathrm{O}_{2}\right)$. These compounds $\mathrm{H}_{2} \mathrm{~S}$ and $\mathrm{H}_{2} \mathrm{O}_{2}$ are produced by certain microorganisms (CFNS, 2006). In this study, refrigerated and frozen spent

Table 2. Changes in pH values of spent hen's meat at different storage temperatures under room temperature storage condition

\begin{tabular}{|c|c|c|c|c|c|c|c|}
\hline \multirow{3}{*}{\multicolumn{2}{|c|}{$\begin{array}{l}\text { Analysis procedures \& } \\
\text { Storage periods }(\mathrm{h})\end{array}$}} & \multicolumn{6}{|c|}{ Parts } \\
\hline & & \multicolumn{3}{|c|}{ Refrigeration ${ }^{1)}$} & \multicolumn{3}{|c|}{ Frozen $^{2)}$} \\
\hline & & Breast & Leg & Wing & Breast & Leg & Wing \\
\hline \multirow{5}{*}{$\begin{array}{l}1^{\text {st }} \text { analysis } \\
\text { on room } \\
\text { temperature }\end{array}$} & $2 \mathrm{~d}+0$ & $6.72 \pm 0.03^{\mathrm{A} 3)}$ & $6.71 \pm 0.05^{\mathrm{CD}}$ & $6.91 \pm 0.02^{\mathrm{E}}$ & $6.12 \pm 0.04^{\mathrm{ABC}}$ & $7.27 \pm 0.01^{\mathrm{A}}$ & $6.84 \pm 0.02^{\mathrm{A}}$ \\
\hline & $2 \mathrm{~d}+2$ & $6.37 \pm 0.11^{\mathrm{D}}$ & $7.11 \pm 0.05^{\mathrm{EF}}$ & $6.66 \pm 0.01^{\mathrm{C}}$ & $6.00 \pm 0.11^{\mathrm{DEFG}}$ & $6.91 \pm 0.03^{\mathrm{CD}}$ & $6.72 \pm 0.03^{\mathrm{C}}$ \\
\hline & $2 d+6$ & $6.28 \pm 0.02^{\mathrm{E}}$ & $6.85 \pm 0.05^{\mathrm{DE}}$ & $6.78 \pm 0.01^{\mathrm{F}}$ & $6.06 \pm 0.10^{\mathrm{CDE}}$ & $6.81 \pm 0.11^{\mathrm{DE}}$ & $6.62 \pm 0.03^{\mathrm{DEF}}$ \\
\hline & $2 d+12$ & $6.27 \pm 0.10^{\mathrm{E}}$ & $6.56 \pm 0.02^{\mathrm{FG}}$ & $6.52 \pm 0.04^{\mathrm{F}}$ & $5.97 \pm 0.03^{\mathrm{FGH}}$ & $6.82 \pm 0.02^{\mathrm{DE}}$ & $6.80 \pm 0.05^{\mathrm{AB}}$ \\
\hline & $2 \mathrm{~d}+24$ & $6.05 \pm 0.01^{\mathrm{G}}$ & $6.93 \pm 0.02^{\mathrm{G}}$ & $6.45 \pm 0.04^{\mathrm{D}}$ & $6.04 \pm 0.03^{\mathrm{CDEF}}$ & $6.68 \pm 0.03^{\mathrm{FG}}$ & $6.41 \pm 0.04^{\mathrm{H}}$ \\
\hline \multirow{5}{*}{$\begin{array}{l}2^{\text {nd }} \text { analysis } \\
\text { on room } \\
\text { temperature }\end{array}$} & $6 \mathrm{~d}+0$ & $5.99 \pm 0.06^{\mathrm{G}}$ & $6.86 \pm 0.07^{\mathrm{GH}}$ & $6.42 \pm 0.03^{\mathrm{D}}$ & $5.99 \pm 0.06^{\mathrm{EFGH}}$ & $6.76 \pm 0.10^{\mathrm{EF}}$ & $6.74 \pm 0.03^{\mathrm{C}}$ \\
\hline & $6 d+2$ & $6.02 \pm 0.06^{\mathrm{G}}$ & $6.87 \pm 0.02^{\mathrm{FG}}$ & $6.29 \pm 0.02^{\mathrm{D}}$ & $5.93 \pm 0.03^{\mathrm{HG}}$ & $6.70 \pm 0.01^{\mathrm{FG}}$ & $6.47 \pm 0.03^{\mathrm{G}}$ \\
\hline & $6 d+6$ & $5.97 \pm 0.07^{\mathrm{G}}$ & $6.95 \pm 0.04^{\mathrm{H}}$ & $6.24 \pm 0.02^{\mathrm{D}}$ & $6.04 \pm 0.01^{\mathrm{CDEF}}$ & $6.68 \pm 0.07^{\mathrm{FG}}$ & $6.77 \pm 0.02^{\mathrm{BC}}$ \\
\hline & $6 d+12$ & $5.87 \pm 0.02^{\mathrm{H}}$ & $7.23 \pm 0.11^{\mathrm{GH}}$ & $6.41 \pm 0.02^{\mathrm{ABC}}$ & $6.11 \pm 0.01^{\mathrm{ABC}}$ & $6.43 \pm 0.01^{\mathrm{I}}$ & $6.75 \pm 0.01^{\mathrm{BC}}$ \\
\hline & $6 \mathrm{~d}+24$ & $6.04 \pm 0.06^{\mathrm{G}}$ & $7.22 \pm 0.01^{\mathrm{GH}}$ & $6.41 \pm 0.01^{\mathrm{ABC}}$ & $5.91 \pm 0.02^{\mathrm{H}}$ & $6.66 \pm 0.01^{\mathrm{FG}}$ & $6.60 \pm 0.03^{\mathrm{F}}$ \\
\hline \multirow{5}{*}{$\begin{array}{l}3^{\text {rd }} \text { analysis } \\
\text { on room } \\
\text { temperature }\end{array}$} & $10 \mathrm{~d}+0$ & $6.16 \pm 0.02^{\mathrm{F}}$ & $7.18 \pm 0.04^{\mathrm{BCD}}$ & $6.96 \pm 0.06^{\mathrm{BC}}$ & $6.19 \pm 0.13^{\mathrm{A}}$ & $6.60 \pm 0.03^{\mathrm{HG}}$ & $6.60 \pm 0.02^{\mathrm{EF}}$ \\
\hline & $10 \mathrm{~d}+2$ & $6.22 \pm 0.06^{\mathrm{EF}}$ & $7.16 \pm 0.04^{\mathrm{AB}}$ & $7.11 \pm 0.06^{\mathrm{BC}}$ & $6.16 \pm 0.02^{\mathrm{AB}}$ & $6.54 \pm 0.03^{\mathrm{H}}$ & $6.60 \pm 0.02^{\mathrm{F}}$ \\
\hline & $10 \mathrm{~d}+6$ & $6.52 \pm 0.06^{\mathrm{B}}$ & $7.23 \pm 0.07^{\mathrm{DE}}$ & $7.01 \pm 0.01^{\mathrm{ABC}}$ & $6.08 \pm 0.06^{\mathrm{BCD}}$ & $7.00 \pm 0.02^{\mathrm{C}}$ & $6.66 \pm 0.02^{\mathrm{D}}$ \\
\hline & $10 d+12$ & $6.50 \pm 0.01^{\mathrm{C}}$ & $7.29 \pm 0.03^{\mathrm{ABC}}$ & $7.05 \pm 0.01^{\mathrm{AB}}$ & $6.07 \pm 0.05^{\mathrm{CDE}}$ & $7.15 \pm 0.01^{\mathrm{CD}}$ & $6.66 \pm 0.03^{\mathrm{DE}}$ \\
\hline & $10 d+24$ & $6.41 \pm 0.03^{\mathrm{D}}$ & $7.36 \pm 0.05^{\mathrm{A}}$ & $7.20 \pm 0.05^{\mathrm{A}}$ & $6.08 \pm 0.05^{\mathrm{BCDE}}$ & $7.15 \pm 0.02^{\mathrm{B}}$ & $6.50 \pm 0.05^{\mathrm{G}}$ \\
\hline
\end{tabular}

\footnotetext{
${ }^{1)}$ Samples (stored at refrigerated condition) to room temperature

${ }^{2)}$ Samples (stored at frozen condition) to room temperature

${ }^{3)}$ Means \pm SD

${ }^{\text {A-I } M e a n s ~ w i t h ~ t h e ~ d i f f e r e n t ~ s u p e r s c r i p t ~ i n ~ t h e ~ s a m e ~ c o l u m n ~ a r e ~ s i g n i f i c a n t l y ~ d i f f e r e n t ~}(p<0.05)$.
} 

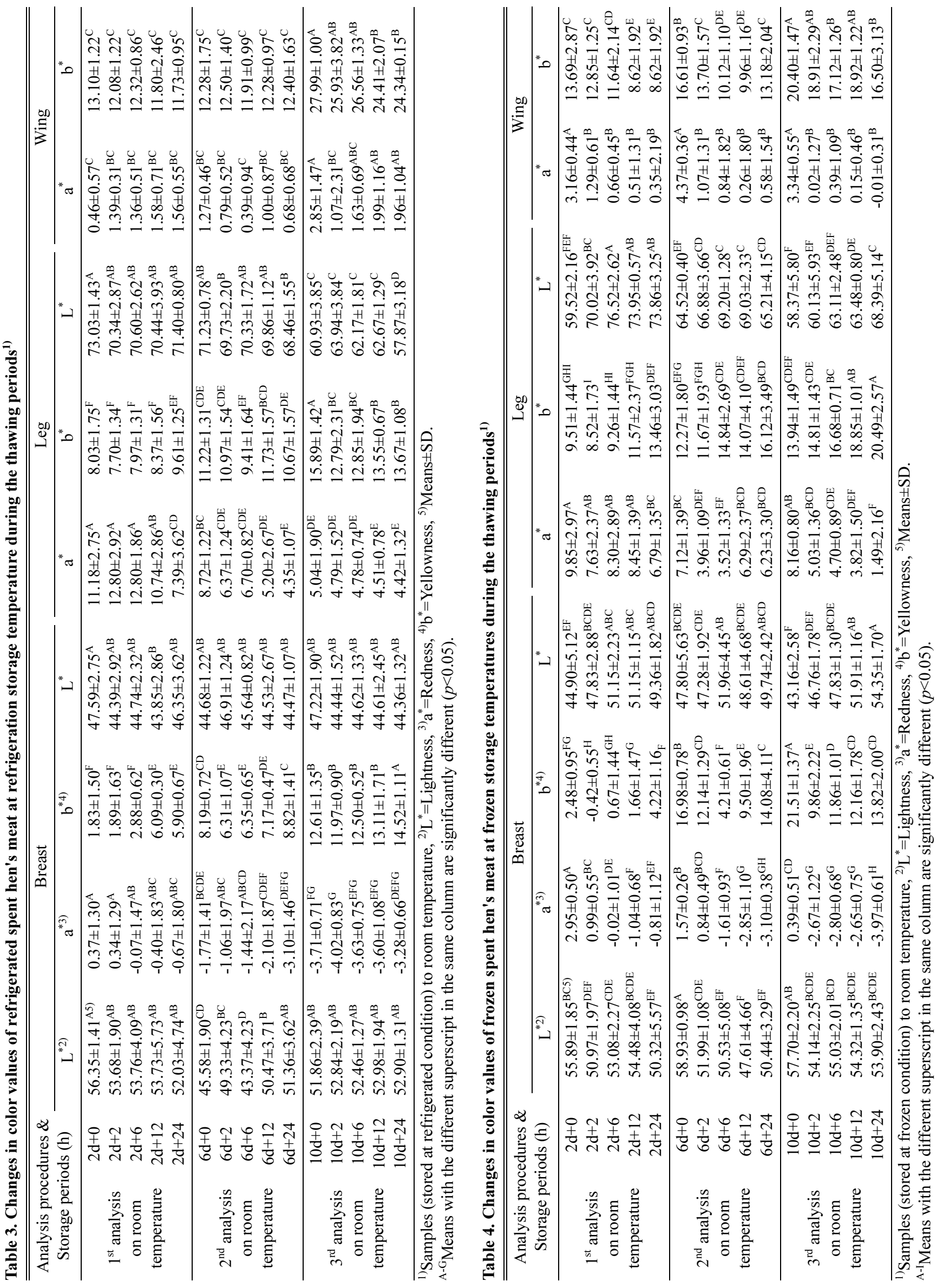
hen breast meats were observed under room temperature storage conditions.

\section{K- value}

The K-values of refrigerated and frozen spent hen meats were affected by storage temperature under room temperature storage condition (Table 5).

Terasaki et al. (1965) suggested that the K-value was an effective index of meat quality, especially for poultry. Many studies have found correlations between some of these metabolites or their ratios and freshness in some fish species (Hattula and Kiesvaara, 1996).

Adenosine triphosphate (ATP) is the main source of energy in muscle for biochemical reactions. After death, ATP is rapidly converted into adenosine diphosphate (ADP) and adenosine monophosphate (AMP) with w subsequent accumulation of inosine 5'-monophophate (IMP), which is further degraded into inosine $\left(\mathrm{H}_{\mathrm{X}} \mathrm{R}\right)$ and hypoxanthin (Hx) (Hernández-Cázares et al., 2011).

Jolley et al. (1981) reported that the ATP concentration at any time post-slaughter was dependent on two factors: (a) the length of time during which the delay phase was operative and (b) the subsequent rate of ATP depletion. The quality of poultry products is significantly affected by its freshness and generally, fresh meats have a small
K-value.

During the $1^{\text {st }}$ analysis, the K-value index of refrigerated breast, leg and wing meats was $41.6 \%, 65.7 \%$, and $59.0 \%$, respectively, whereas the K-value index of each part of the frozen meats was $35.4 \%, 56.8 \%$, and $54.8 \%$, respectively. K-value index $60 \%$ is defined as phase of initial spoilage to evaluate the degree of freshness and refrigerated spent hen leg meats exceeded at $1^{\text {st }}$ analysis (Hashiguchi et al., 1984; Usui, 1979).

The smallest change in the K-value was observed on frozen breast meats, which resulted in a longer shelf life on the storage. K-values of refrigerated leg meats significantly increased from 28.8 to $96.3(p<0.05)$, which showed higher increase than other meat components.

\section{VBN}

The changes in VBN values of refrigerated and frozen spent hen meats were affected by storage temperature under room temperature storage condition (Table 6).

The VBN value is a good indicator of protein deterioration and decomposition. Proteins in meat are decomposed into peptides and amino acids by enzymes and microorganisms when stored under cold conditions (Field and Chang, 1969).

During the $1^{\text {st }}$ analysis, the VBN value of refrigerated

Table 5. Changes in K-values of spent hen's breast meat at different storage temperatures under room temperature storage condition

Unit : \%

\begin{tabular}{|c|c|c|c|c|c|c|c|}
\hline \multirow{3}{*}{\multicolumn{2}{|c|}{$\begin{array}{l}\text { Analysis procedures \& } \\
\text { Storage periods }(\mathrm{h})\end{array}$}} & \multicolumn{6}{|c|}{ Parts } \\
\hline & & \multicolumn{3}{|c|}{ Refrigeration ${ }^{1)}$} & \multicolumn{3}{|c|}{ Frozen $^{2)}$} \\
\hline & & Breast & Leg & Wing & Breast & Leg & Wing \\
\hline \multirow{5}{*}{$\begin{array}{l}1^{\text {st }} \text { analysis } \\
\text { on room } \\
\text { temperature }\end{array}$} & $2 \mathrm{~d}+0$ & $30.0 \pm 1.41^{\mathrm{F} 3)}$ & $28.8 \pm 1.13^{\mathrm{F}}$ & $26.7 \pm 0.99^{\mathrm{L}}$ & $30.1 \pm 1.78^{\mathrm{F}}$ & $29.4 \pm 1.91^{\mathrm{H}}$ & $28.6 \pm 0.12^{\mathrm{H}}$ \\
\hline & $2 d+2$ & $34.9 \pm 1.20^{\mathrm{F}}$ & $29.4 \pm 1.34^{\mathrm{F}}$ & $30.0 \pm 0.92^{\mathrm{L}}$ & $29.7 \pm 0.47^{\mathrm{F}}$ & $35.6 \pm 2.05^{\mathrm{G}}$ & $31.6 \pm 1.88^{\mathrm{H}}$ \\
\hline & $2 d+6$ & $46.1 \pm 0.99^{\mathrm{CDE}}$ & $35.1 \pm 2.97^{\mathrm{F}}$ & $42.4 \pm 0.92^{\mathrm{K}}$ & $30.0 \pm 2.63^{\mathrm{F}}$ & $33.6 \pm 1.37^{\mathrm{GH}}$ & $30.1 \pm 0.67^{\mathrm{H}}$ \\
\hline & $2 \mathrm{~d}+12$ & $42.6 \pm 2.30^{\mathrm{DE}}$ & $57.6 \pm 7.50^{\mathrm{E}}$ & $55.2 \pm 2.85^{\mathrm{J}}$ & $34.9 \pm 2.29 \mathrm{C}^{\mathrm{DE}}$ & $46.6 \pm 1.95^{\mathrm{F}}$ & $47.7 \pm 3.82^{\mathrm{G}}$ \\
\hline & $2 d+24$ & $41.6 \pm 4.74^{\mathrm{DEF}}$ & $65.7 \pm 0.14^{\mathrm{D}}$ & $59.0 \pm 2.47^{\mathrm{IJ}}$ & $35.4 \pm 3.12^{\mathrm{BCDE}}$ & $56.8 \pm 2.75^{\mathrm{E}}$ & $54.8 \pm 0.75^{\mathrm{F}}$ \\
\hline \multirow{5}{*}{$\begin{array}{l}2^{\text {nd }} \text { analysis } \\
\text { on room } \\
\text { temperature }\end{array}$} & $6 \mathrm{~d}+0$ & $39.6 \pm 0.64^{\mathrm{DEF}}$ & $71.7 \pm 6.36^{\mathrm{CD}}$ & $60.6 \pm 1.77^{\mathrm{HI}}$ & $32.7 \pm 1.28^{\mathrm{EF}}$ & $65.4 \pm 2.90^{\mathrm{D}}$ & $56.2 \pm 1.95^{\mathrm{EF}}$ \\
\hline & $6 d+2$ & $44.7 \pm 0.78^{\mathrm{DE}}$ & $76.3 \pm 2.69^{\mathrm{C}}$ & $65.7 \pm 3.68^{\mathrm{GH}}$ & $34.1 \pm 0.64^{\mathrm{DE}}$ & $65.7 \pm 2.79^{\mathrm{D}}$ & $58.5 \pm 0.74^{\mathrm{E}}$ \\
\hline & $6 d+6$ & $44.5 \pm 2.90^{\mathrm{DE}}$ & $85.3 \pm 0.21^{\mathrm{B}}$ & $69.1 \pm 4.31^{\mathrm{FG}}$ & $34.5 \pm 1.18^{\mathrm{DE}}$ & $65.6 \pm 4.47^{\mathrm{D}}$ & $63.3 \pm 2.08^{\mathrm{D}}$ \\
\hline & $6 d+12$ & $48.3 \pm 2.55^{\mathrm{CD}}$ & $94.8 \pm 0.42^{\mathrm{A}}$ & $74.4 \pm 7.57^{\mathrm{EF}}$ & $34.6 \pm 1.34^{\mathrm{DE}}$ & $67.2 \pm 1.97^{\mathrm{CD}}$ & $65.8 \pm 2.20^{\mathrm{D}}$ \\
\hline & $6 \mathrm{~d}+24$ & $49.4 \pm 4.38^{\mathrm{CD}}$ & $96.0 \pm 1.41^{\mathrm{A}}$ & $77.2 \pm 1.41^{\mathrm{DE}}$ & $36.7 \pm 0.91^{\mathrm{ABCD}}$ & $67.5 \pm 4.33^{\mathrm{CD}}$ & $70.4 \pm 1.80^{\mathrm{C}}$ \\
\hline \multirow{5}{*}{$\begin{array}{l}3^{\text {rd }} \text { analysis } \\
\text { on room } \\
\text { temperature }\end{array}$} & $10 \mathrm{~d}+0$ & $48.8 \pm 1.84^{\mathrm{CD}}$ & $96.3 \pm 1.77^{\mathrm{A}}$ & $81.2 \pm 1.48^{\mathrm{CD}}$ & $38.2 \pm 0.64^{\mathrm{ABC}}$ & $71.6 \pm 1.31^{\mathrm{BC}}$ & $73.4 \pm 2.04^{\mathrm{BC}}$ \\
\hline & $10 \mathrm{~d}+2$ & $48.8 \pm 3.89^{\mathrm{CD}}$ & $-4)$ & $85.4 \pm 1.41^{\mathrm{BC}}$ & $39.5 \pm 3.56^{\mathrm{A}}$ & $74.3 \pm 1.86^{\mathrm{B}}$ & $74.2 \pm 2.90^{\mathrm{B}}$ \\
\hline & $10 d+6$ & $57.5 \pm 6.22^{\mathrm{BC}}$ & - & $87.9 \pm 2.33^{\mathrm{AB}}$ & $38.5 \pm 1.08^{\mathrm{AB}}$ & $86.6 \pm 1.35^{\mathrm{A}}$ & $75.8 \pm 1.41^{\mathrm{AE}}$ \\
\hline & $10 d+12$ & $63.4 \pm 1.20^{\mathrm{AB}}$ & - & $89.5 \pm 1.34^{\mathrm{AB}}$ & $37.5 \pm 0.45^{\mathrm{ABCD}}$ & $86.0 \pm 1.97^{\mathrm{A}}$ & $76.9 \pm 1.47^{\mathrm{AE}}$ \\
\hline & $10 d+24$ & $72.9 \pm 5.44^{\mathrm{A}}$ & - & $92.8 \pm 2.47^{\mathrm{A}}$ & $38.3 \pm 2.65^{\mathrm{ABC}}$ & $82.4 \pm 3.69^{\mathrm{A}}$ & $78.0 \pm 2.43^{\mathrm{A}}$ \\
\hline
\end{tabular}

\footnotetext{
${ }^{1)}$ Samples (stored at refrigerated condition) to room temperature

${ }^{2)}$ Samples (stored at frozen condition) to room temperature

${ }^{3)} \mathrm{Means} \pm \mathrm{SD}$

4)-, means more than $100 \%$.

${ }^{\mathrm{A}-\mathrm{L}}$ Means with the different superscript in the same column are significantly different $(p<0.05)$.
} 
Table 6. Changes in VBN (volatile basic nitrogen) of spent hen's meat at different storage temperatures under room temperature storage condition

\begin{tabular}{|c|c|c|c|c|c|c|c|}
\hline \multirow{3}{*}{\multicolumn{2}{|c|}{$\begin{array}{l}\text { Analysis procedures \& } \\
\text { Storage periods }(\mathrm{h})\end{array}$}} & \multicolumn{6}{|c|}{ Parts } \\
\hline & & \multicolumn{3}{|c|}{ Refrigeration $^{1)}$} & \multicolumn{3}{|c|}{ Frozen $^{2)}$} \\
\hline & & Breast & Leg & Wing & Breast & Leg & Wing \\
\hline \multirow{5}{*}{$\begin{array}{l}1^{\text {st }} \text { analysis } \\
\text { on room } \\
\text { temperature }\end{array}$} & $2 \mathrm{~d}+0$ & $13.17 \pm 0.40^{\mathrm{F} 3)}$ & $8.68 \pm 0.32^{\mathrm{J}}$ & $8.40 \pm 0.79^{\mathrm{GH}}$ & $10.37 \pm 0.32^{\mathrm{F}}$ & $6.72 \pm 0.46^{\mathrm{G}}$ & $5.60 \pm 0.79^{\mathrm{F}}$ \\
\hline & $2 d+2$ & $12.61 \pm 0.32^{\mathrm{F}}$ & $13.17 \pm 1.19^{\mathrm{I}}$ & $7.56 \pm 0.32^{\mathrm{GH}}$ & $12.61 \pm 0.32^{\mathrm{DE}}$ & $7.84 \pm 0.79^{\mathrm{G}}$ & $5.32 \pm 1.19^{\mathrm{F}}$ \\
\hline & $2 d+6$ & $12.89 \pm 0.79^{\mathrm{F}}$ & $14.29 \pm 0.40^{\mathrm{I}}$ & $5.88 \pm 0.40^{\mathrm{H}}$ & $12.05 \pm 0.40^{\mathrm{E}}$ & $8.12 \pm 1.19^{\mathrm{G}}$ & $5.32 \pm 1.19^{\mathrm{F}}$ \\
\hline & $2 d+12$ & $12.61 \pm 0.40^{\mathrm{F}}$ & $24.93 \pm 0.40^{\mathrm{H}}$ & $5.32 \pm 0.40^{\mathrm{H}}$ & $10.37 \pm 1.99^{\mathrm{F}}$ & $8.12 \pm 1.98^{\mathrm{G}}$ & $4.76 \pm 0.32^{\mathrm{F}}$ \\
\hline & $2 d+24$ & $13.17 \pm 0.40^{\mathrm{F}}$ & $24.20 \pm 0.31^{\mathrm{H}}$ & $7.84 \pm 0.45^{\mathrm{GH}}$ & $9.53 \pm 0.80^{\mathrm{F}}$ & $12.61 \pm 0.32^{\mathrm{F}}$ & $5.60 \pm 0.79^{\mathrm{F}}$ \\
\hline \multirow{5}{*}{$\begin{array}{l}2^{\text {nd }} \text { analysis } \\
\text { on room } \\
\text { temperature }\end{array}$} & $6 d+0$ & $14.01 \pm 0.79^{\mathrm{F}}$ & $30.82 \pm 2.38^{\mathrm{G}}$ & $10.65 \pm 0.79^{\mathrm{FG}}$ & $14.01 \pm 0.00^{\mathrm{C}}$ & $12.61 \pm 0.40^{\mathrm{F}}$ & $8.68 \pm 0.40^{\mathrm{E}}$ \\
\hline & $6 d+2$ & $23.81 \pm 0.40^{\mathrm{D}}$ & $28.85 \pm 1.19^{\mathrm{G}}$ & $16.25 \pm 3.96^{\mathrm{E}}$ & $13.73 \pm 0.32^{\mathrm{CD}}$ & $14.85 \pm 0.40^{\mathrm{E}}$ & $8.68 \pm 0.40^{\mathrm{E}}$ \\
\hline & $6 d+6$ & $23.81 \pm 0.40^{\mathrm{D}}$ & $48.47 \pm 5.15^{\mathrm{F}}$ & $14.29 \pm 0.40^{\mathrm{EF}}$ & $13.45 \pm 0.79^{\mathrm{CD}}$ & $22.13 \pm 0.40^{\mathrm{D}}$ & $9.53 \pm 0.80^{\mathrm{E}}$ \\
\hline & $6 d+12$ & $22.41 \pm 1.58^{\mathrm{E}}$ & $58.27 \pm 3.17^{\mathrm{E}}$ & $14.01 \pm 0.79^{\mathrm{EF}}$ & $12.61 \pm 0.40^{\mathrm{DE}}$ & $21.94 \pm 0.71^{\mathrm{D}}$ & $9.19 \pm 1.98^{\mathrm{E}}$ \\
\hline & $6 d+24$ & $21.01 \pm 0.40^{\mathrm{DE}}$ & $60.51 \pm 0.46^{\mathrm{E}}$ & $38.10 \pm 1.58^{\mathrm{D}}$ & $13.73 \pm 0.40^{\mathrm{CD}}$ & $22.41 \pm 3.17^{\mathrm{D}}$ & $9.81 \pm 0.40^{\mathrm{DE}}$ \\
\hline \multirow{5}{*}{$\begin{array}{l}3^{\text {rd }} \text { analysis } \\
\text { on room } \\
\text { temperature }\end{array}$} & $10 \mathrm{~d}+0$ & $22.41 \pm 1.58^{\mathrm{D}}$ & $60.79 \pm 0.32^{\mathrm{E}}$ & $38.10 \pm 1.58^{\mathrm{D}}$ & $14.57 \pm 0.79^{\mathrm{BC}}$ & $23.81 \pm 0.32^{\mathrm{D}}$ & $10.93 \pm 1.19^{\mathrm{DE}}$ \\
\hline & $10 \mathrm{~d}+2$ & $24.37 \pm 0.32^{\mathrm{D}}$ & $66.40 \pm 0.32^{\mathrm{D}}$ & $38.66 \pm 6.34^{\mathrm{D}}$ & $15.41 \pm 0.40^{\mathrm{B}}$ & $23.78 \pm 0.35^{\mathrm{D}}$ & $12.05 \pm 0.40^{\mathrm{D}}$ \\
\hline & $10 \mathrm{~d}+6$ & $35.02 \pm 1.19^{\mathrm{C}}$ & $74.52 \pm 0.40^{\mathrm{C}}$ & $47.34 \pm 1.98^{\mathrm{C}}$ & $13.73 \pm 0.40^{\mathrm{CD}}$ & $30.41 \pm 1.80^{\mathrm{C}}$ & $17.37 \pm 2.38^{\mathrm{C}}$ \\
\hline & $10 d+12$ & $39.50 \pm 0.32^{\mathrm{B}}$ & $87.68 \pm 0.32^{\mathrm{B}}$ & $58.27 \pm 3.17^{\mathrm{B}}$ & $15.41 \pm 0.32^{\mathrm{B}}$ & $36.70 \pm 0.32^{\mathrm{B}}$ & $22.13 \pm 0.40^{\mathrm{B}}$ \\
\hline & $10 d+24$ & $44.54 \pm 0.32^{\mathrm{A}}$ & $96.93 \pm 2.38^{\mathrm{A}}$ & $69.47 \pm 0.00^{\mathrm{A}}$ & $19.05 \pm 0.79^{\mathrm{A}}$ & $46.50 \pm 2.38^{\mathrm{A}}$ & $30.54 \pm 1.20^{\mathrm{A}}$ \\
\hline
\end{tabular}

${ }^{1)}$ Samples (stored at refrigerated condition) to room temperature

${ }^{2)}$ Samples (stored at frozen condition) to room temperature

${ }^{3)}$ Means \pm SD

${ }^{\text {A-J } M e a n s ~ w i t h ~ t h e ~ d i f f e r e n t ~ s u p e r s c r i p t ~ i n ~ t h e ~ s a m e ~ c o l u m n ~ a r e ~ s i g n i f i c a n t l y ~ d i f f e r e n t ~}(p<0.05)$.

breast meat and frozen wing meat were not influenced by storage temperature by elapsing storage periods $(p<0.05)$. The smallest change in VBN value was observed for frozen breast meats. VBN value significantly increased from $60.79 \mathrm{mg} \%$ to $96.93 \mathrm{mg} \%$ in refrigerated leg meat at $3^{\text {rd }}$ analysis $(p<0.05)$ and the difference was about $36 \mathrm{mg} \%$. The VBN value of refrigerated leg meats reached up to $96.93 \mathrm{mg} \%$.

Davies and Board (1998) suggested that a VBN value of $20 \mathrm{mg} \%$ can be used as a threshold value to evaluate the degree of freshness of raw and packed meat. The frozen breast meats did not exceed this range during the storage periods $(p<0.05)$.

During the $1^{\text {st }}, 2^{\text {nd }}$ and $3^{\text {rd }}$ analysis, the VBN values of both refrigerated and frozen leg meats were the highest. In this study, the VBN values as well as total viable cell counts were the highest in leg meat. This result was consistent with a previous report, where an increase in the VBN value was shown to be associated with the growth of bacteria and protein deterioration (Kang et al., 2002).

\section{Conclusions}

Overall, inappropriate control of temperature accelerated the changes in freshness and physicochemical properties of spent hen meats even when the samples were exposed to room temperature over a short period of time. Thus, it is highly important to maintain the appropriate storage temperature during distribution in order to ensure food safety and freshness of poultry meat products, which will require implementation of the cold chain system.

\section{Acknowledgement}

This research was supported by Korea Institute of Planning and Evaluation for Technology in Food, Agriculture, Forestry and Fisheries (608001-05-3-SB130), Technology Development Program for Agriculture and Forestry, Republic of Korea. The authors also were partially supported by Research center Export of Poultry Products, Republic of Korea.

\section{References}

1. Akamittath, J. G., Brekke, C. J., and Schanus, E. G. (1990) Lipid oxidation and color stability in restructured meat systems during frozen storage. J. Food Sci. 55, 1513-1517.

2. Barnes, E. M. (1976) Microbiological problem of chicken at refrigeration temperature. J. Sci. Food Agric. 24, 777-781.

3. Center for Disease Control and Prevention (2010) Database: Trends in Foodborne illness, 1996-2010 Available from http: //www.cdc.gov/foodborneburden/surveillance-systems.html.

4. CFNS Food and Nutritional Sciences : Meat Industry Service 
(2006) Database: Colour defects in meat- Part2:Greening, Pinking, Browning \& Sports Available from http://www. meatupdate.csiro.au/MeatQualityIndexPage.htm.

5. Cunningham, F. C. (1982) Microbiological aspects of poultry and muscles and their relationship to tenderness. J. Food Prot. 45, 1149-1164.

6. Davies, A. and Board, R. (1998) The microbiology of meat and poultry. Blackie Academic \& Professional, London, UK, pp. 288.

7. Field, R. A. and Chang, Y. D. (1969) Free amino acids in bovine muscle and their relationship to tenderness. J. Food Sci. 34, 329-331.

8. Geesink, G. H., Koolmees, P. A., van Laack, H. L. J. M., and Smulders, E. J. M. (1995) Determinants of tenderisation in beef longissimus dorsi and triceps brachii muscles. Meat Sci. 41, 7-17.

9. Gill, C. O., Moza, L. F., Badoni, M., and Barbut, S. (2006) The effects on the microbiological condition of product of carcass dressing, cooling, and portioning processes at a poultry packing plant. Int. J. Food Microbiol. 110, 187-193.

10. Hashiguchi, M., Suzuki. K. and Matsunoto, F. (1984) Studies on freshness and rottenness of fresh fish. 1. Changes in Kvalue and deterioration of total lipids of fresh fish during chilled storage. J. Jap. Soc. Food Sci. Tech. 31, 1-9.

11. Hattula, T. and Kiesvaara. M. (1996) Breakdown products of adenosine triphosphate in heated fishery products as an indicator of raw material freshness and of storage quality. $L W T$ Food Sci. Technol. 29, 135-139.

12. Hernández-Cázares, A. S., Aristroy, M. C., and Toldrá, F. (2011) Nucleotides and their degradation products during processing of dry-cured ham, measured by HPLC and an enzyme sensor. Meat Sci. 87, 125-129.

13. Jolley, P. D., Honikle, K. O., and Hamm, R. (1981) Influence of temperature on the rate of post-mortem metabolism and water holding capacity of bovine neck muscle. Meat Sci. 5, 99-107.

14. Juneja, V. K., Melendres, M. V., Huang, L., Gumudavelli, V., Subbiah, J., and Thippareddi. H. (2007) Modelling the effect of temperature on growth of Salmonella in chicken. Food Microbiol. 24, 328-335.

15. Kang, S. N., Jang. A., Lee, S. O., Min, J. S., and Lee, M. (2002) Effect of organic acid on value of VBN, TBARS, color and sensory property of pork meat. Korean J. Anim. Sci. Technol. 44, 443-452.

16. Kessel, A. S., Gillespie, I. A., O’Brien, S. J., Adak, G. K., Humphrey, T. J., and Ward, L. R. (2001) General outbreaks of infectious intestinal disease linked with poultry, England and Wales, 1992-1999. Commun. Dis. Public Health 3, 171177.

17. Lawrie, R. A. (1991) Meat Science. 5th ed, Pergamon Press, NY.

18. Lesiak, M. T., Olson, D. G., Leisak, C. A., and Ahn, D. U. (1996) Effects of postmortem temperature and time on the water-holding capacity of hot-boned turkey breast and leg muscle. Meat Sci. 43, 51-60.
19. Likar, K. and Jevšnik, M. (2006) Cold chain maintaining in food trade. Food Control 17, 108-113.

20. Research Center Export of Poultry Products (2010) Database: Current state of Poultry export(samgyetang, chicken) Available from http://www.ccocco.re.kr/jsp/info/info_export. jsp

21. Northcutt, J. K., Buhr, R. J., Young, L. L., Lyon, C. E., and Ware, G. O. (2001) Influence of age and postchill carcass aging duration on chicken breast fillet quality. Poultry Sci. 80, 808-812.

22. Offer, G. and Knight, P. (1988) The structural basis of waterholding in meat. Part 1. General principles and water uptake in meat processing. 63-171 in: Developments in Meat Science-4. Elsevier Applied Science Publishing Co., Inc., NY.

23. Offer, G. and Trinick, J. (1983) On the mechanism of waterholding in meat: The swelling and Shrinking of myofibrils. Meat Sci. 8, 245-281.

24. Pearson, D. (1968) Assessment of meat freshness in quality control employing chemical techniques: A review. J. Sci. Food Agric. 19, 357-363.

25. Satio, T., Arai, K., and Matsuyoshi, M. (1959) A new method for estimating the freshness of fish. Bull. Jpn. Soc. Sci. Fish 24, 749-750.

26. SAS (2002) SAS/STAT Software. Release 9.2, SAS Institute Inc., Cary, NC, USA.

27. Sofos, J. N. and Smith, G. C. (1998) Nonacid meat decontamination technologies: Model studies and commercial applications. Int. J. Food Microbiol. 44, 171-188.

28. Sofos, J. N., Cabedo, L., Zerby, H., Belk, K. E., and Smith, G. C. (2000) Potential interaction between antioxidant and microbial meat quality. In Decker, E., Faustman, C., and LopezBote, C. J. (Eds.). Antioxidant in muscle food. New York. Wiley, pp. 427-453.

29. Terasaki, M., Kajikawa, M., Fujita E., and Ishii, K. (1965) Studies on the flavor of meats. Part : Formation and degradation of inosinic acid in meat. Agric. Biol. Chem. 29, 208-211.

30. Thomas, J. M. and Matthews, K. R. (2005) Food microbiology: an introduction. ASM Press, Washington, DC, pp. 247250.

31. Usui, K. (1979) Changes of ATP derivatives in quail meat during storage. Bull. Fac. Agric. 45, 53-56.

32. Vaithiyanathan, S., Naveena, B. M., Muthukumar, M., Girish, P. S., Ramakrishna, C., Sen, A. R., and Babji, Y. (2008) Biochemical and physicochemical changes in spent hen breast meat during postmortem aging. Poultry Sci. 87, 180187.

33. Zhao, C., Ge, B., De Villena, J., Sudler, R., Yeh, E., Zhao, E., White, D. G., Wagner, D., and Meng, J. (2001) Prevalence of Camphylobacter spp., Escherichia coli, and Salmonella serovars in retail chicken, turkey, pork, and beef from the greater Washington, DC, area. Appl. Environ. Microbiol. 67, 5431-5436.

(Received 2012.3.5/Revised 1st 2012.4.11, 2nd 2012.4.20, 3rd 2012.5.7/Accepted 2012.6.1) 